\title{
MAPPING OF LAND USE CHANGES IN THE CORE ZONE OF PARANGTRITIS SAND DUNES USING OBIA METHOD 2015-2020
}

\author{
Latifa Melani Putri ${ }^{1}$, Pramaditya Wicaksono ${ }^{2}$ \\ 1Program Studi D3 Penginderaan Jauh dan Sistem Informasi Geografi, Sekolah Vokasi, \\ Universitas Gadjah Mada \\ 2Departemen Sains Informasi Geografi, Fakultas Geografi, Universitas Gadjah Mada \\ Jl. Kaliurang, Sekip Utara, Bulaksumur, Sleman, Yogyakarta, 55281, Indonesia \\ e-mail: prama.wicaksono@ugm.ac.id
}

Received : 17 December 2020, Repaired: 05 January 2021, Approved: 08 January 2021

\begin{abstract}
Abstrak
Indonesia memiliki banyak jenis bentuklahan yang unik dan langka, salah satunya adalah gumuk pasir yang terletak di wilayah Parangtritis, Daerah Istimewa Yogyakarta. Gumuk pasir memiliki fungsi utama sebagai kawasan konservasi, tembok alami bencana tsunami, kawasan resapan air, serta habitat untuk flora fauna gumuk pasir. Namun, keberadaan gumuk pasir saat ini terancam punah oleh adanya penurunan luasannya, yang disebabkan oleh perubahan penggunaan lahan. Setiap tahun, penggunaan lahan di gumuk pasir Parangtritis mengalami perubahan, yang akhirnya menyebabkan luasan gumuk pasir selalu berkurang setiap tahunnya. Oleh karena itu, pemetaan perubahan penggunaan lahan penting untuk dilakukan untuk mengetahui perubahan yang terjadi di zona inti gumuk pasir. Penelitian ini bertujuan untuk memetakan perubahan penggunaan lahan di zona inti gumuk pasir menggunakan foto udara format kecil dan metode OBIA (ObjectBased Image Analysis). Penggunaan lahan di wilayah kajian diklasifikasikan menjadi sembilan kelas yaitu gumuk pasir, hutan lahan kering, semak belukar, beting pantai, lahan terbuka, lahan terbangun dan permukiman, ladang, jalan dan tambak. Hasil penelitian menunjukkan adanya perubahan pada semua kelas penggunaan lahan. Berdasarkan uji akurasi, akurasi keseluruhan (overall accuracy) hasil klasifikasi penggunaan lahan tahun 2020 sebesar 68,95\%, sedangkan hasil klasifikasi penggunaan lahan tahun 2015 sebesar $61,81 \%$.
\end{abstract}

Kata kunci: Perubahan Penggunaan Lahan, OBIA, Foto Udara Format Kecil

\begin{abstract}
Indonesia has many types of unique and rare landforms, one of which is sand dunes, which is located in Parangtritis. Sand dune has the main function as a conservation area, natural wall for the tsunami disaster, water catchment area, and habitat for sand dune flora and fauna. However, the existence of sand dunes is currently threatened with extinction due to the decrease in their area, which is caused by changes in land use. Every year, the land use in the Parangtritis sand dune changes. Therefore, it is important to map land use changes to determine the changes that occur in the sand dune core zone. This study aims to map land use change in the core zone of sand dunes using small format aerial images and the OBIA (Object-Based Image Analysis) method. Land use in the study area is classified into nine classes, namely sand dunes, dry land forest, shrubs, coastal shoals, open field, builtup area and settlements, dry land agricultural fields, roads, and fishponds. The results showed that there were changes in all land use classes. Based on the accuracy assessment, the overall accuracy for 2020 was 68.95\%, while the classification results for 2015 were $61.81 \%$.
\end{abstract}

Keywords: land use changes, OBIA, Small Format Aerial Photography 


\section{INTRODUCTION}

Sand dunes is one of the landforms from aeloin process in the form of large sand dunes that resemble hills caused by wind movement (Sihotang, 2014). Volcanic ash material from volcanoes is carried by river flows and deposited along the coastline, and then the sand deposits are pushed by the wind and a large sand dune formed (Budiyanto, 2011). One of the famous sand dunes in Indonesia is located at the coast of Parangtritis, Yogyakarta Special Region (DIY) Province. Parangtritis sand dune area is divided into three zones, namely the core zone, the support zone, and the zone of limited designation. Sand dunes have important functions, especially as a conservation area, tsunami relief, water catchment areas and sand dune flora and fauna habitat (Hendrastuti et al., 2018). However, the area of sand dunes is decreasing every year due to the development of ecotourism activities. Some examples of new land use developed in sand dune areas are new beaches, such as Barchan Beach, Cemara Sewu Beach and Pelangi Beach. The tourism sectors developed in the core zone of the sand dune including the rental of jeeps and atvs operated right on the stretch of the sand dune to the center. Laily et al. (2018) stated that there was a significant decrease in sand dunes area between 1972 2015. This is very unfortunate considering that sand dunes are a geoheritage area that needs to be preserved. Yogyakarta Special Region Regulation Number 4 of 2015 states that sand dunes is one of several natural habitats in the DIY province that must be protected and preserved.

The core zone, as a sand dune conservation area, should be kept clean and free from various land uses. Appeals made by the officials are often ignored because there are no formal regulations on sand dunes. In recent years, there are many new buildings and vegetation have started to increase in the sand dune area. The building intended as a tourism facility, such as toilets, food stalls, and even jeep and ATV rental places. New buildings and vegetation that grows around the sand dune area will have an impact on the development of the sand dune. Therefore, it is necessary to make land use mapping to monitor land use changes that occur in the sand dune core zone. This monitoring effort could be done by utilizing remote sensing technology.

One of the remote sensing technologies that is often used recently is small format aerial photography. Aerial images provide a quick visual inventory in a part of the earth's surface and could be used to create detailed maps (Sirin et al., 2015). Subaryono \& Kurniawan (2008) mentioned some of the advantages of aerial image, such as the scale of the photo that could be made very large with a relatively low flying height, and other than that, the price of equipment and cameras is getting cheaper and widely available in the market. The use classification process could be carried out using the OBIA (Object-Based Image Analysis) method. OBIA is a digital classification method that takes into account the spatial and spectral aspects of the objects (Widayani, 2018). OBIA provides image segmentation, attributes, classification as well as processing and connecting individual objects (segments) in space and time (Hay \& Castilla, 2006). This method is so popular to use for classification because besides being time efficient, this method also produces classification with a good level of accuracy. Simamora et al. (2015) stated that OBIA is a superior classification approach compared to other classification methods. Although OBIA can produce an accurate classification result, an accuracy assessment must still be conducted to validate the classification result.

Mapping changes in land use are commonly performed, especially for sand dunes which is a dynamic and constantly changing landform. This research was not only conducted to identify and analyze changes that happens to the sand dune, but also to find out their conformity to the recommendations made by the Geographic Information Agency and Universitas Gadjah Mada in 2015, along with the Parangtritis sand dune zoning. The recommendation was issued to help preserve the sand dune 
without harming the people around the sand dune. However, since this is not a formal regulation, the recommendations are often not implemented and even forgotten. Even though these recommendations have not yet adapted as formal regulations, they could serve as a reference for conducting sand dune-related research. Furthermore, the use of OBIA as a data processing method makes it possible to produce classification with a high level of accuracy. This approach is popularly used for classifying land use using high spastial resolution images.

Through this land use mapping, it is expected to help monitoring the development and changes in the Parangtritis sand dune area. The land use change monitoring is expected to provide the latest information about the conformity and land use changes that occur in the Parangtritis sand dune area.

\section{RESEARCH METHODOLOGY}

Generally, this research has been divided into three phases: data preparation, data processing, and data completion. The data preparation phase consists of preparing the data that will be used in the study. The data processing phase includes all data processing carried out to obtain research results, and the completion phase includes all activities to complete the data processing and analysis. The research was conducted in the core zone of the Parangtritis sand dune, which is located in the Kretek sub-district, Bantul district, Yogyakarta Special Region (Figure 1). The core zone of the sand dune was selected because it is functioned as a conservation area. However, currently, this function tends to be neglected.

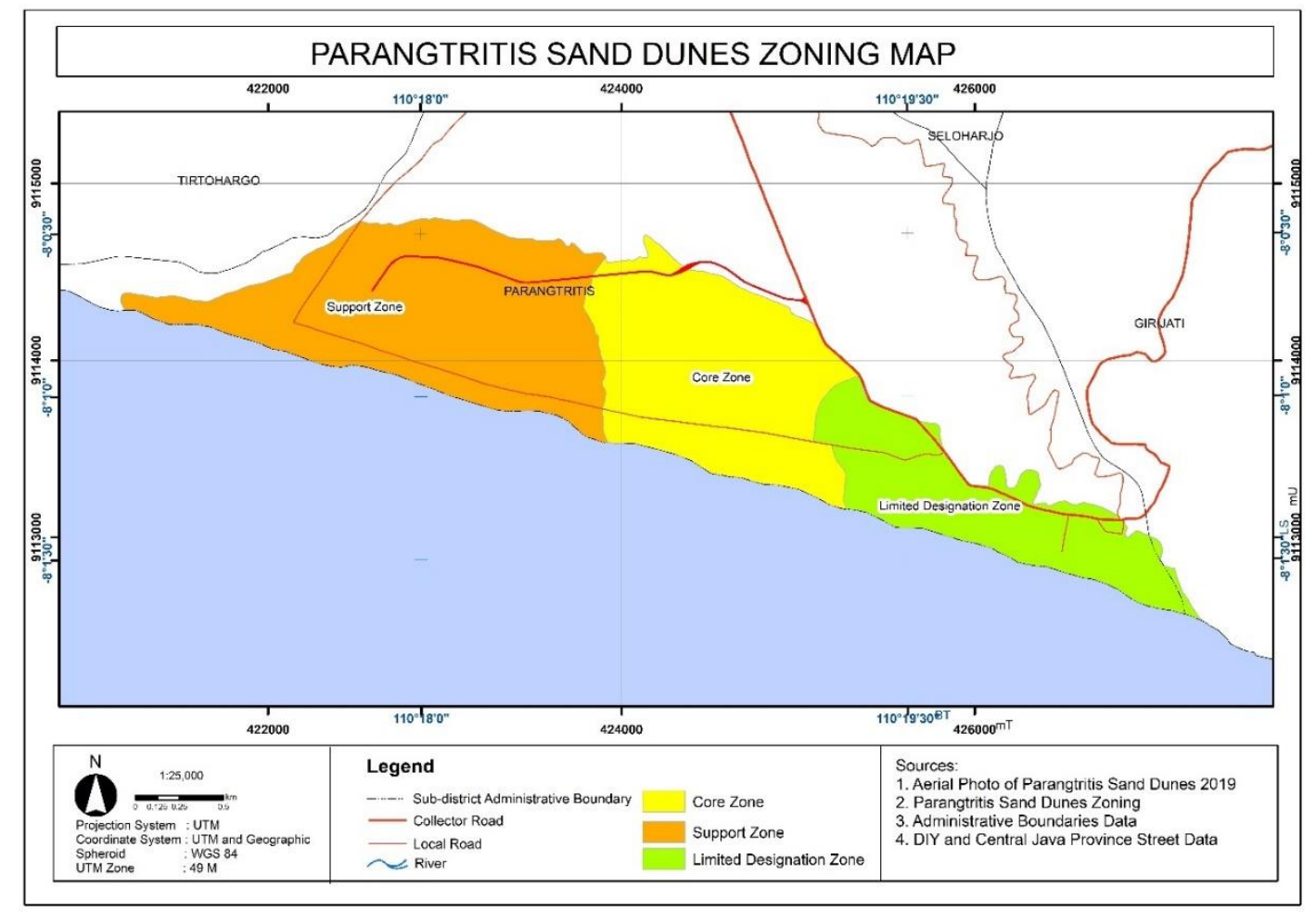

Figure 1. Map showing the location of the study area.

The data used in this study include small format aerial images of the Parangtritis sand dune acquired in 2015 and 2020 as the main data used for data processing. In addition, the Parangtritis sand dune shapefile zoning data was used to determine the borders of the sand dune core zone. The three data were obtained from the Parangtritis Geomaritime Science Park agency. Figure 2 and Figure 3 below are the aerial photographs used to perform the data processing. 


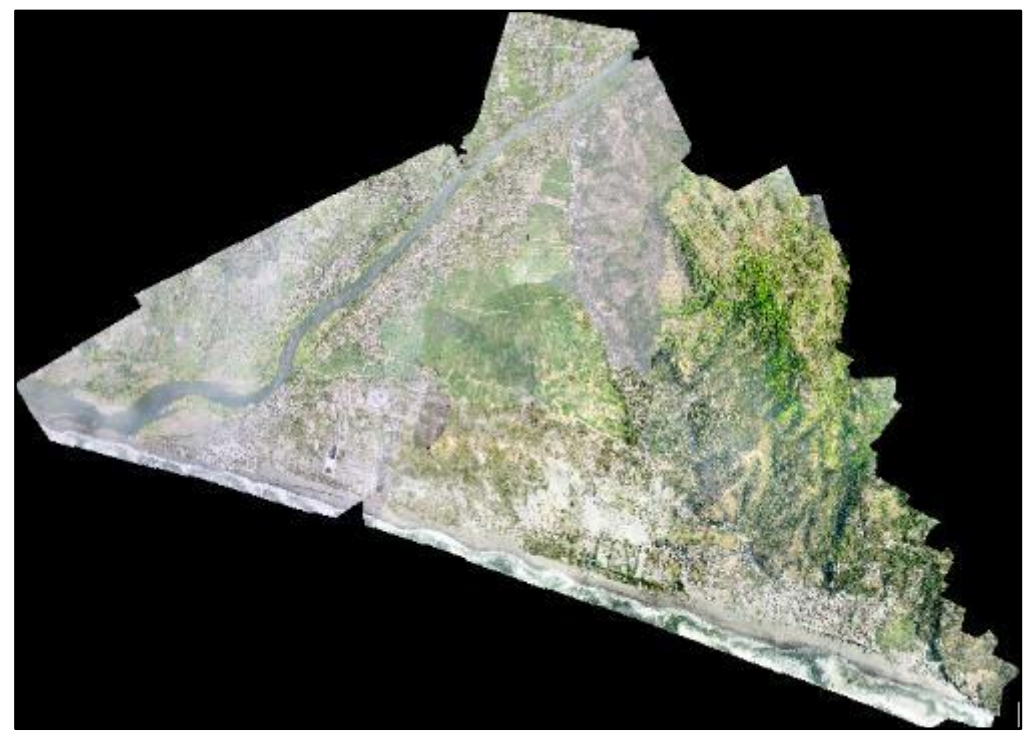

Figure 2. Aerial image part of Kretek Sub-district in 2015

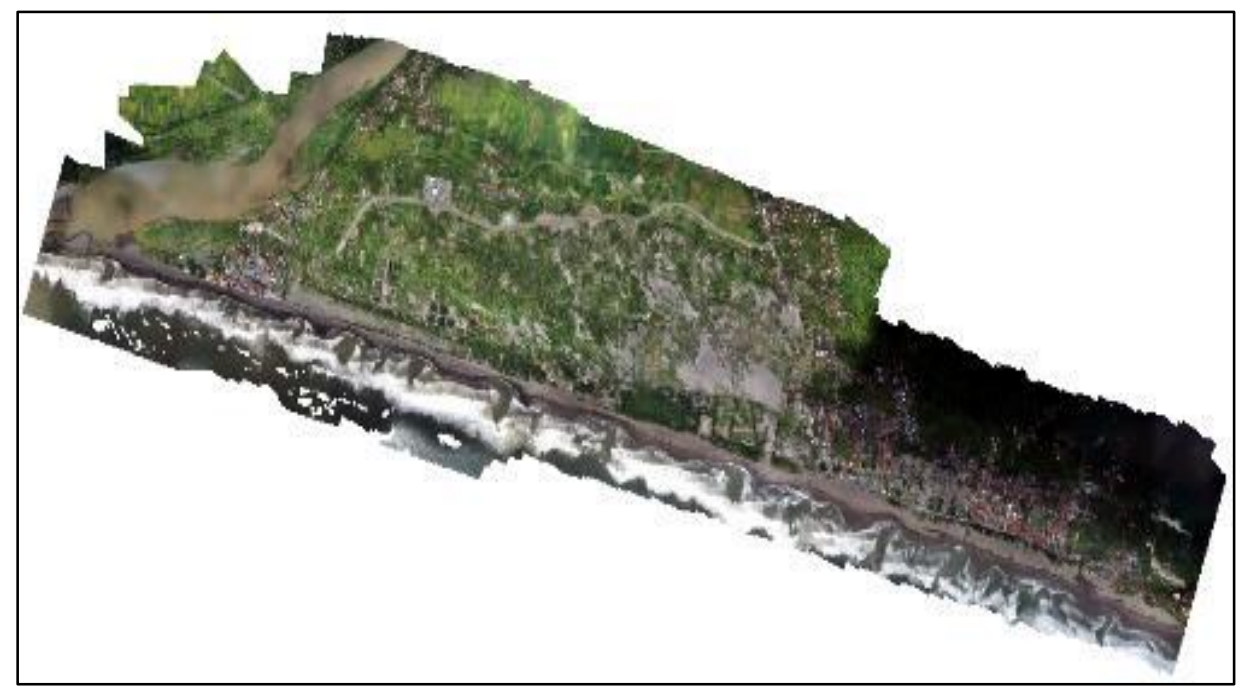

Figure 3. Aerial image of Parangtritis Sand Dunes in 2020

The data processing phase was divided into several steps. The first is to segment and classify aerial photos in 2015 and 2020. Second, to assess the accuracy of the classification results, and finally to calculate and compare land use changes. Aerial photo segmentation was carried out to divide an image into homogeneous pixels. Segmentation was done using a multiresolution segmentation algorithm based on several parameters, i.e., scale, shape, color, compactness, and smoothness. Multiresolution segmentation is able to separate objects fairly well and the combination of the aforementioned parameters can produce a suitable segment for image classification (Setiani et al., 2016).
The segmentation process was carried out on a trial-and-error basis to get the most optimal segmentation results. The process for parameters' trial and error was carried out one by one starting from determining the scale of parameters. Scale is a very important parameter for determining segment size and affects the occurrence of oversegmentation and undersegmentation. The next step is determining the shape and color parameters. These two parameters influence the process of object segmentation. Regions with multiple color variations were given higher scores on the color parameter, while regions with significant textural differences were assigned high scores on the shape parameter. Likewise, with the 
compactness and smoothness parameters, the area which is dominated by compact objects must be given a high value on the compactness parameter.

After the segmentation process has been completed, the next step was to classify the resulting segments. According to Asma (2018), classification is a process of grouping pixels with similar characteristics in the image. Classification process was carried out using a sample-based classification method with the nearest neighbor algorithm. Sample-based classification was carried out by comparing the average pixel value of objects with training samples (Syarif, 2017). This classification method can provide accurate results with a relatively short processing time. Classification was carried out on nine land use classes, i.e., dry land forest, shrubs, dry land agricultural field, open field, built-up area and settlements, roads, sand dunes, beach shoals, and fishponds.

The resulting classification was assessed its accuracy using confusion matrix method (Congalton \& Green, 2008), by comparing the classification results with reference data. The confusion matrix table displays the user's accuracy, producer's accuracy, and overall accuracy.

Reference map used in this study are based on a visual interpretation of aerial images. The reference maps were created using visual interpretation by considering the interpretation keys, such as hue / color, shape, texture, pattern, size, height, and association. In the process of land use intepretation, we also pay attention to the land use data for that year, which was obtained through the attachment of the sand dune restoration study and the PGSP agency. After the accuracy assessment is completed, the next step is to carry out land use changes analysis.

As mentioned previously, the reference data used should be verified. The 2015 data could be compared with the 2015 land use map issued by PGSP, while the 2020 data was verified via field survey. The survey process was carried out by checking each land use class on a map generated through visual interpretation. Beside that, the field survey can also assist the segment classification process during OBIA, by adding local insight of the land use variation in the study area. Figure 4 shows the research flowchart.

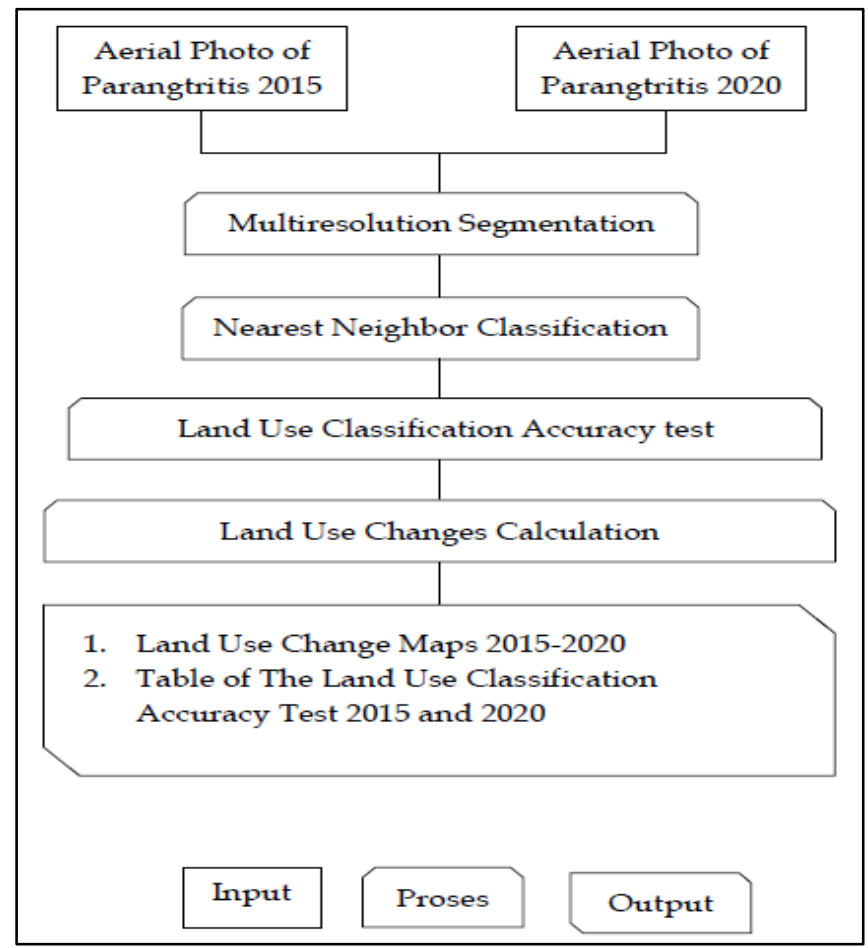

Figure 4. Research flowchart 


\section{RESULT AND DISCUSSION Segmentation}

The segmentation process was conducted in several attempts to find the best value of the scale, shape, color, compactness and softness parameters. The experimental results show that the value of the parameter used in the two aerial images is the same. This is possible given that both are the same area with similar land uses. The first experiment was carried out to determine the scale parameters. The scale used will affect the size of the segment formed and directly related to appearance of oversegmentation and undersegmentation. The determination of the scale value was divided into two large experiments, the first experiment carried out with a scale of 50 , 100, 150, and 200. These experiments have shown that the scale of 100 is the best. The second experiment was carried out with the scale values of 90, 100, 110 and 120 . Through the second experiment, the 110 scale was the most optimal scale for segmentation. These two experiments show that there are several errors caused by the appearance of oversegmentation and undersegmentation as shown in Figure 5 below.

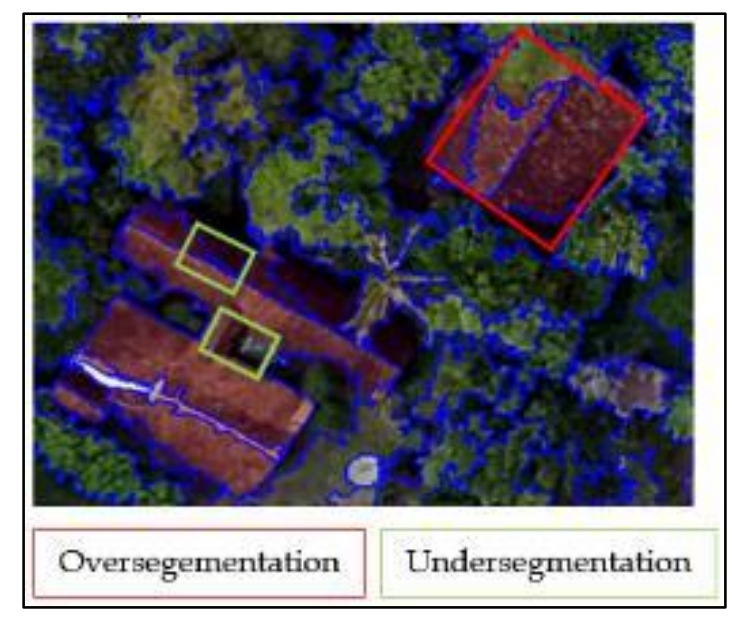

Figure 5. Segmentation error

Further experiments were conducted on shape and color parameters. These two parameters are related to each other. The value of these two parameters was determined based on the condition of the study area. In this research, the study area had many lands uses with quite significant variations in color. Beside that, some of the objects also have spatial characteristics that are quite similar to each other, such as dry land forest with shrubs, and sand dunes with beach shoals. Therefore, higher value was assigned to the color parameter than the value for the shape parameter. After several experiments, the result shows that the optimal value for the color and shape parameter is 0.6 and 0.4 , respectively.

Following this, an experiment was carried out for the parameters of compactness and smoothness. Determining the value of these two parameters must also consider the condition of the study area. In this case, the research area has a variety of objects such as compact or non-compact objects. Therefore, we decided to give balanced values on the compactness and smoothness parameters. Figure 6 shows the results of the aerial photo segmentation with the most optimal value for the five parameters used.

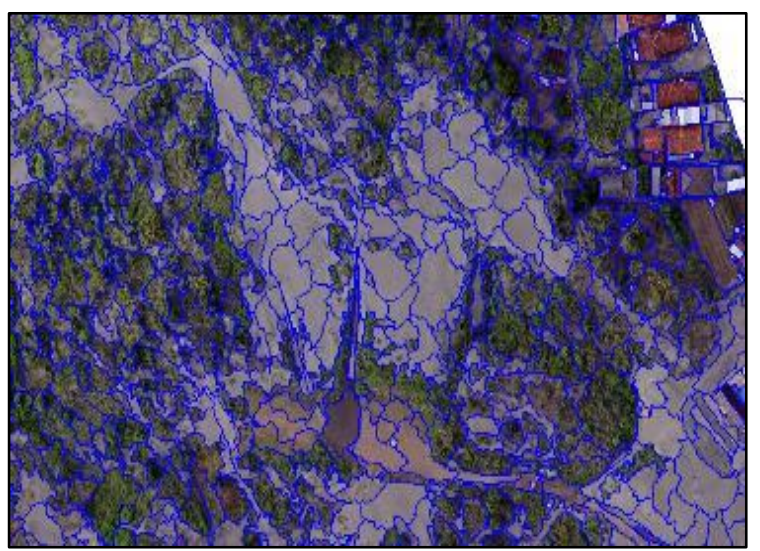

Figure 6. Segmentation result with the scale of 110 , color/shape $0.6 / 0.4$, dan compactness/smoothness 0.5/0.5

\section{Classification}

The process of image classification of 2015 and 2020 aerial images was carried out similarly. Classification process was carried out by sampling each of the land use class as shown in Figure 7. Sampling was conducted in such a way to cover all the variation ofland use classes in the study area. 


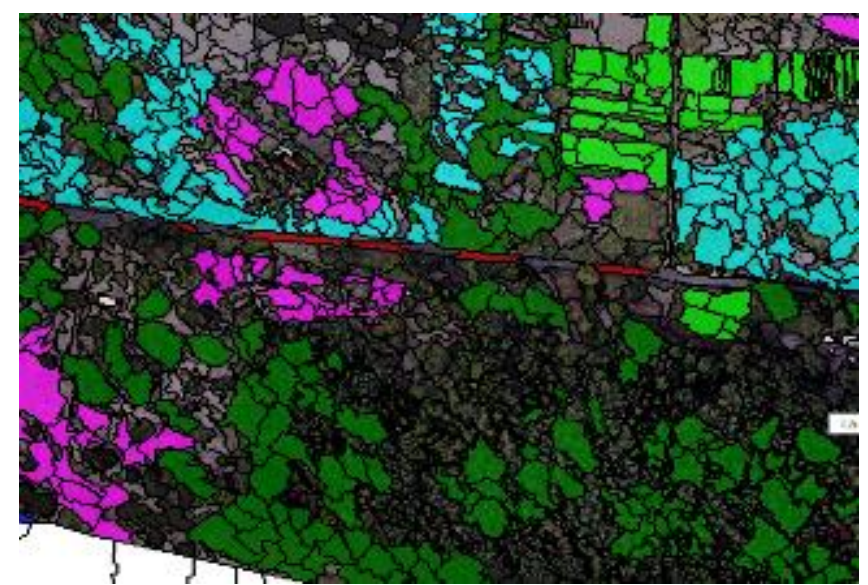

Figure 7. Land use sampling. Dark green indicates dryland forest samples, light green indicates dry land agricultrual field samples, pink indicates open fields samples, and cyan indicates shrubs samples.

After the sampling process, the next step is to determine which feature space used to distinguish one object from another. In this study, the feature space used is layer values, which are sufficient enough to distinguish objects. Feature space could be used to adjust the condition of the study area.

There are errors that may occur when conducting the classification, such as the sample not being able to represent the object sufficiently so that the classification results are not very good. Some of these errors could be caused by segmentation errors and object recognition errors earlier. This could be overcomed in several ways, such as by increasing the number of samples, taking a more representative sample, and rearranging the use of feature space. After going through several experiments, the result of the land use classification is shown in Figure 8.

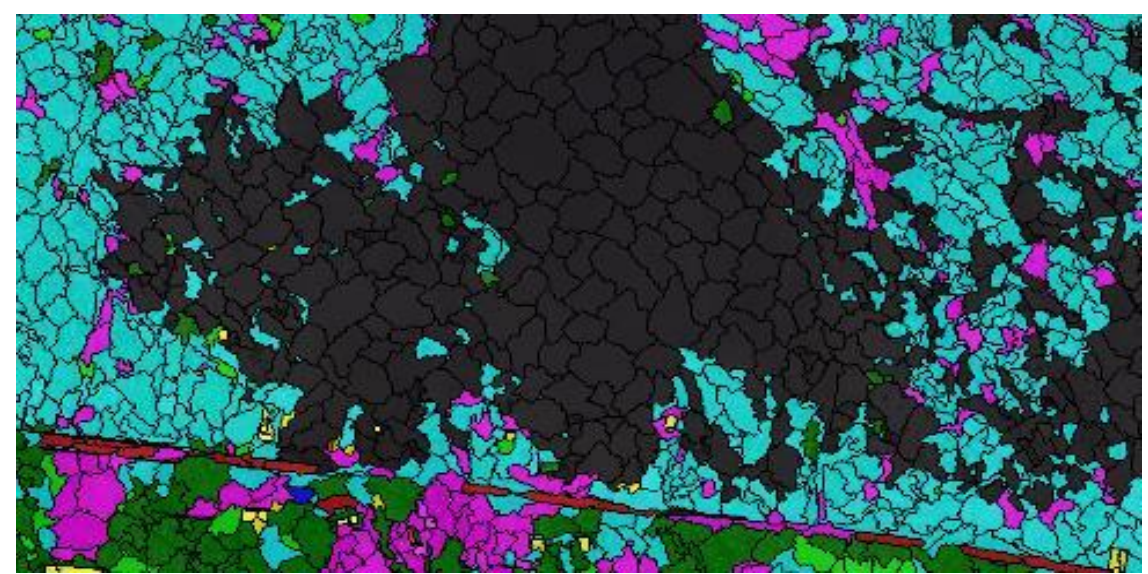

Figure 8. Results of land use classification. The black color classification shows sand dunes, cyan shows shrubs, pink shows open field, red represents roads, dark green represents dry land forest, and light green represents dry land agricultural fields.

\section{Classification Accuracy Assessment}

The 2015 classification accuracy assessment was conducted out by comparing the classification result with a reference map. Reference map for 2015 was obtained through visual interpretation of
2015 aerial image by considering land use map issued by the PGSP agency. Based on this comparison, the accuracy assessment result was presented as a confusion matrix table. 
Table 1. Confusion matrix of 2015 land use classification result

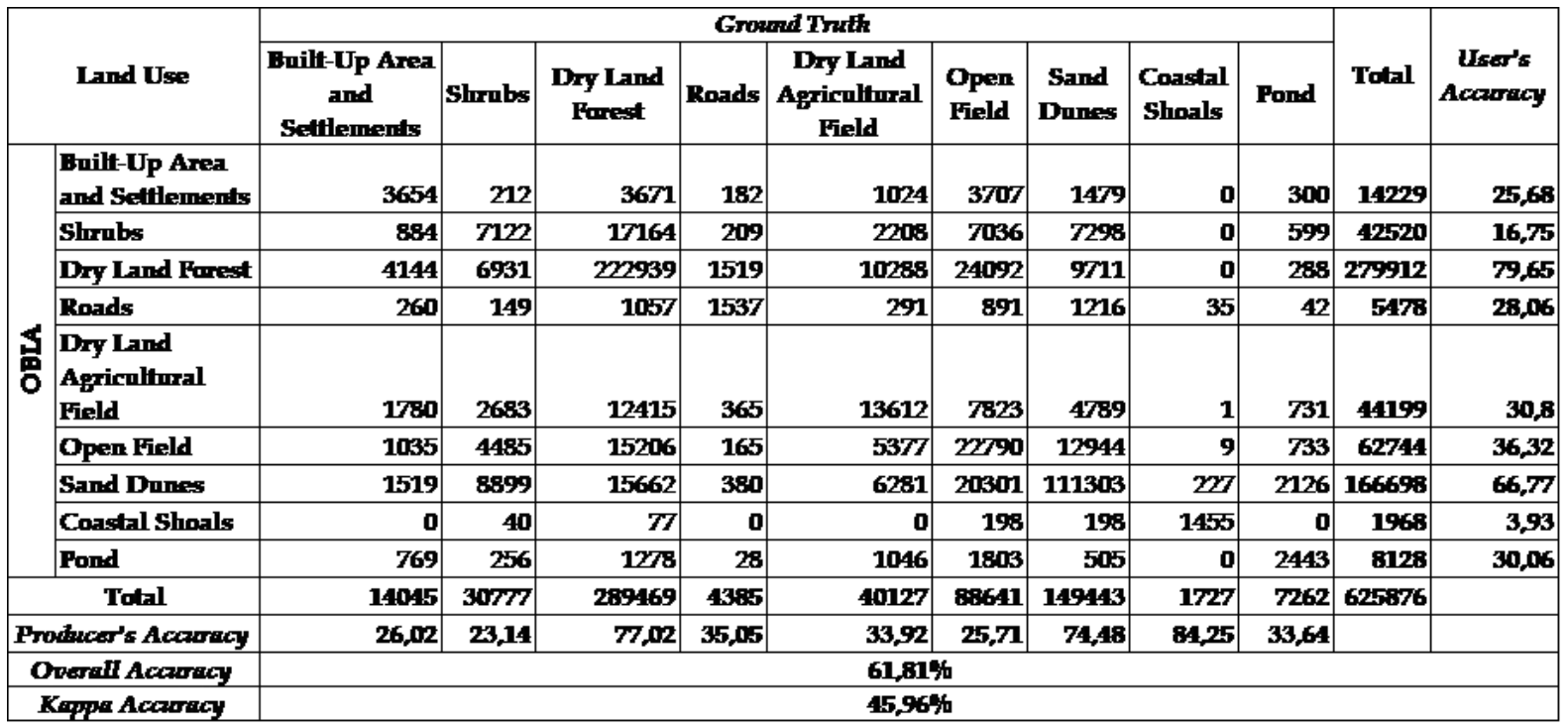

Based on Table 1, the class with highest user's accuracy is dry land forest with $79.65 \%$, and the lowest is shrubs with $16.75 \%$. This is because dry land forest is the most dominating land use and has very distinct spatial characteristics. In contrast, shrubs that are visually similar to dry forest tend to be less prominent. Then, the highest producer's accuracy value was coastal shoals with $84.25 \%$ and the smallest is shrubs with a value of $23.14 \%$. This value is due to the similarity factor between shrubs and other land uses and makes shrubs difficult to be accurately classified. Meanwhile, the high accuracy of coastal shoals is because this land use has spatial characteristics that are quite different from other land uses.

In general, the classification accuracy obtained was categorized as moderate, with an overall accuracy of $61.81 \%$.

\section{Classification Accuracy Assessment}

The reference map used in this accuracy assessment was created by visual interpretation of 2020 aerial image with attention to the 2019 land use map and through field validation.

Table 2. Confusion matrix of 2020 land use classification result

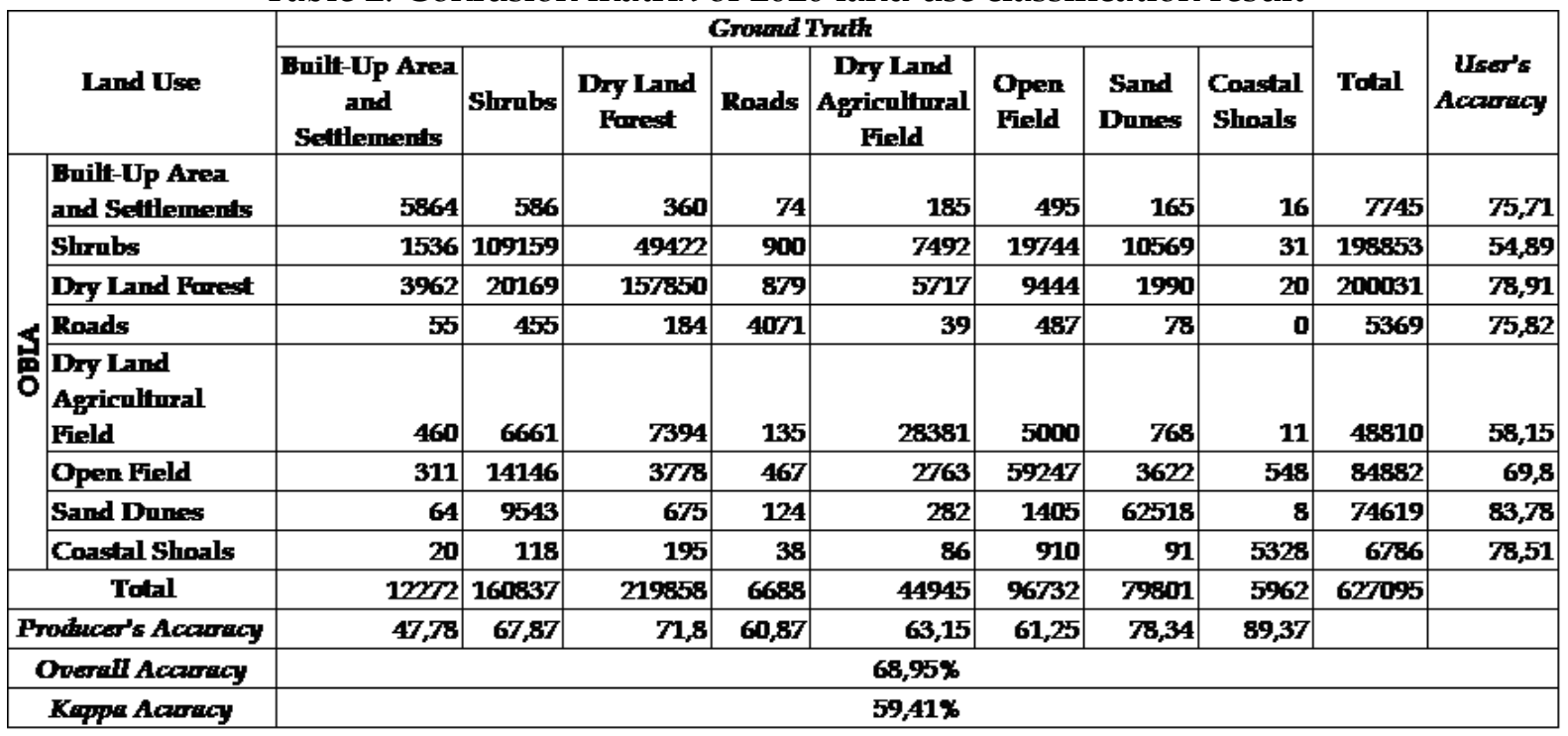


Based on Table 2, the class with highest user's accuracy is sand dune with $83.78 \%$ and the lowest is shrubs with $54.89 \%$. This occurs because sand dunes class is the main land use in the study area with the most prominent characteristics and unique compared to all other land uses. Meanwhile, shrubs have the lowest accuracy due to the many misclassification that causes shrubs class misclassified as dry land forest.

The highest producer's accuracy is coastal shoals with $89.37 \%$ and the lowest is constructed land and settlements with $47.78 \%$. This is because the coastal shoals have prominent characteristics and settlements has a visual appearance that makes it difficult to identify, especially in settlements with brown roofs that resemble the color of soil.

In general, the classification accuracy was categorized as moderate, with an overall accuracy value of $68.95 \%$.

\section{Land Use Changes}

Land use changes analysis was conducted by comparing land use classification result of 2015 and 2020. Based on the analysis, there were changes in every land use class. The land use area changes are presented in Figure 9.

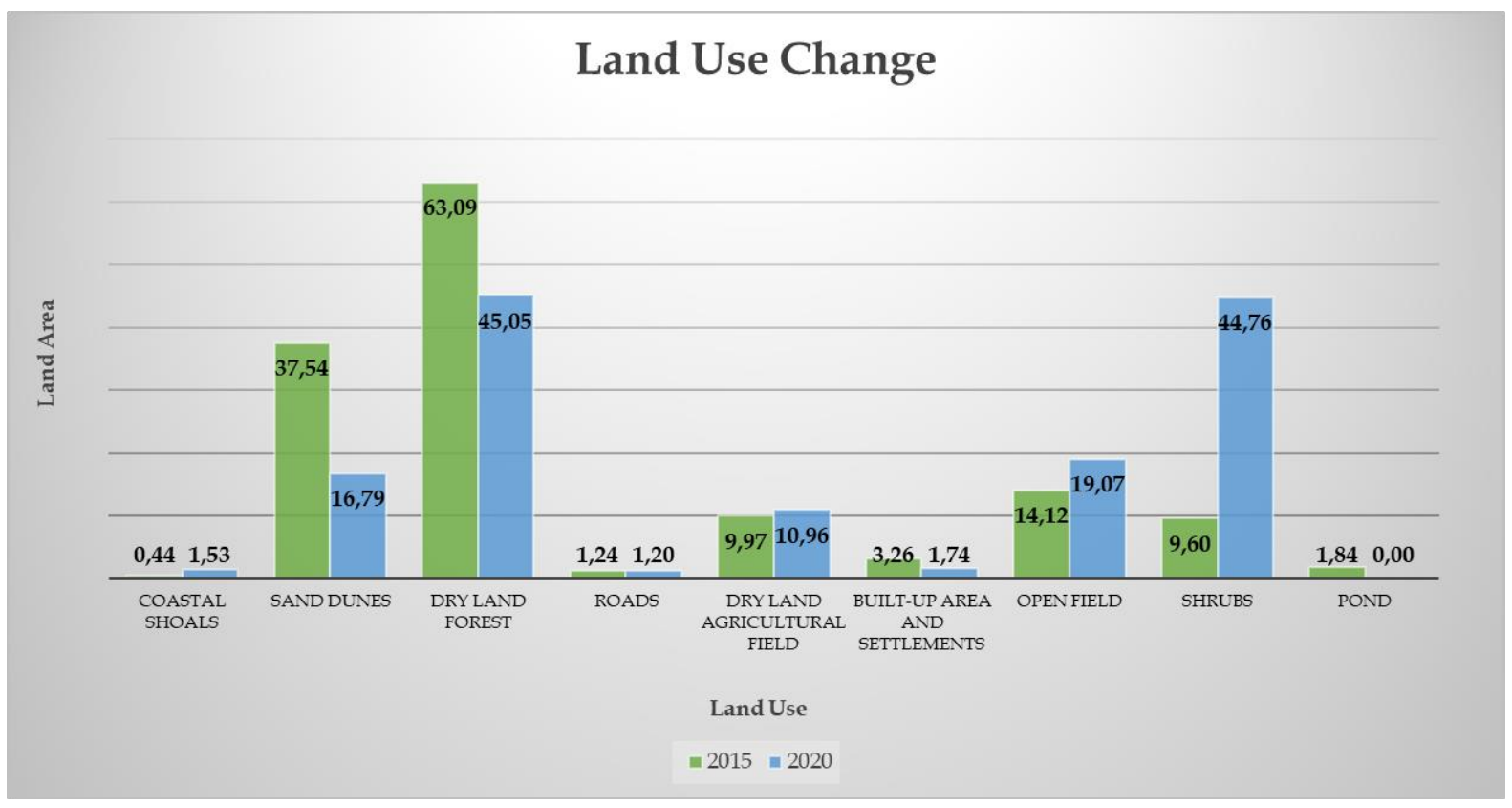

Figure 9. Changes in land use area 2015-2020

The resulting land use changes were not always purely caused by changes that occured in the field but can also be caused by differences in image acquisition time, considering that several land use classes in the study area are strongly influenced by season. Dry land agricultural field was influenced by planting time, so it is possible that during 2015 image acquisition, the fields were not in the planting season. This is rather difficult to explain due to an incomplete image's metadata. Likewise, shrubs also change with season. In the dry season, shrubs will usually turn yellow and wither, so misclassification may occur. Therefore, any changes in the land use area were subject to uncertainties and were not solely due to real changes in the field but also by other factors.

Based on Figure 9, we could see that many changes have occurred in the core zone of the sand dune. Sand dune as the main land use in the area has decreased by 20.75 ha in five years. Meanwhile, shrubs have increased drastically as much as $\mathbf{3 5 . 1 6}$ ha. In addition, fishpond is no longer exists in 2020, even though it has not returned yet to sand dune. The fishponds have 
translocated out from the core zone. As seen in Figure 10, the dark blue color is pond, while the light blue coloris open field. Dry land forest also experienced a slight decline. Some of the reduction occurred due to restoration activities that has been carried out since 2017, especially for built-up area along the road to the sand dune, most of which been removed from the core zone.

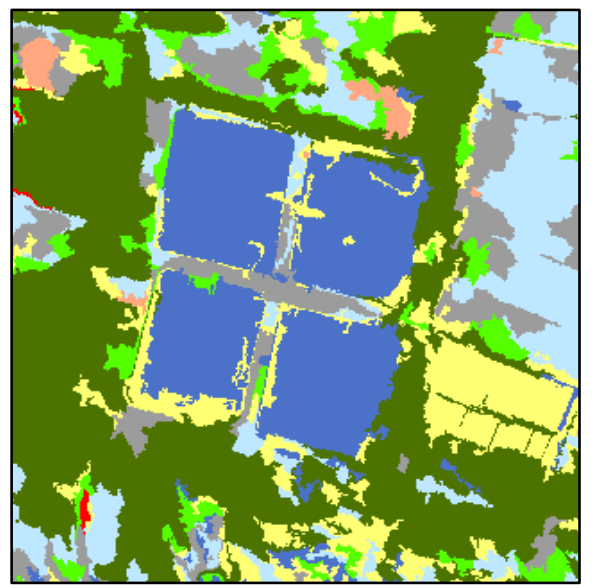

Year 2015

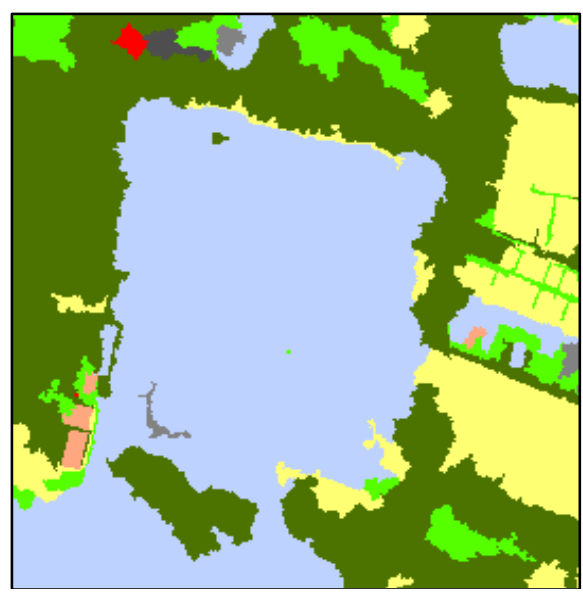

Year 2020

Figure 10. Changes of Fishponds class 2015 - 2020

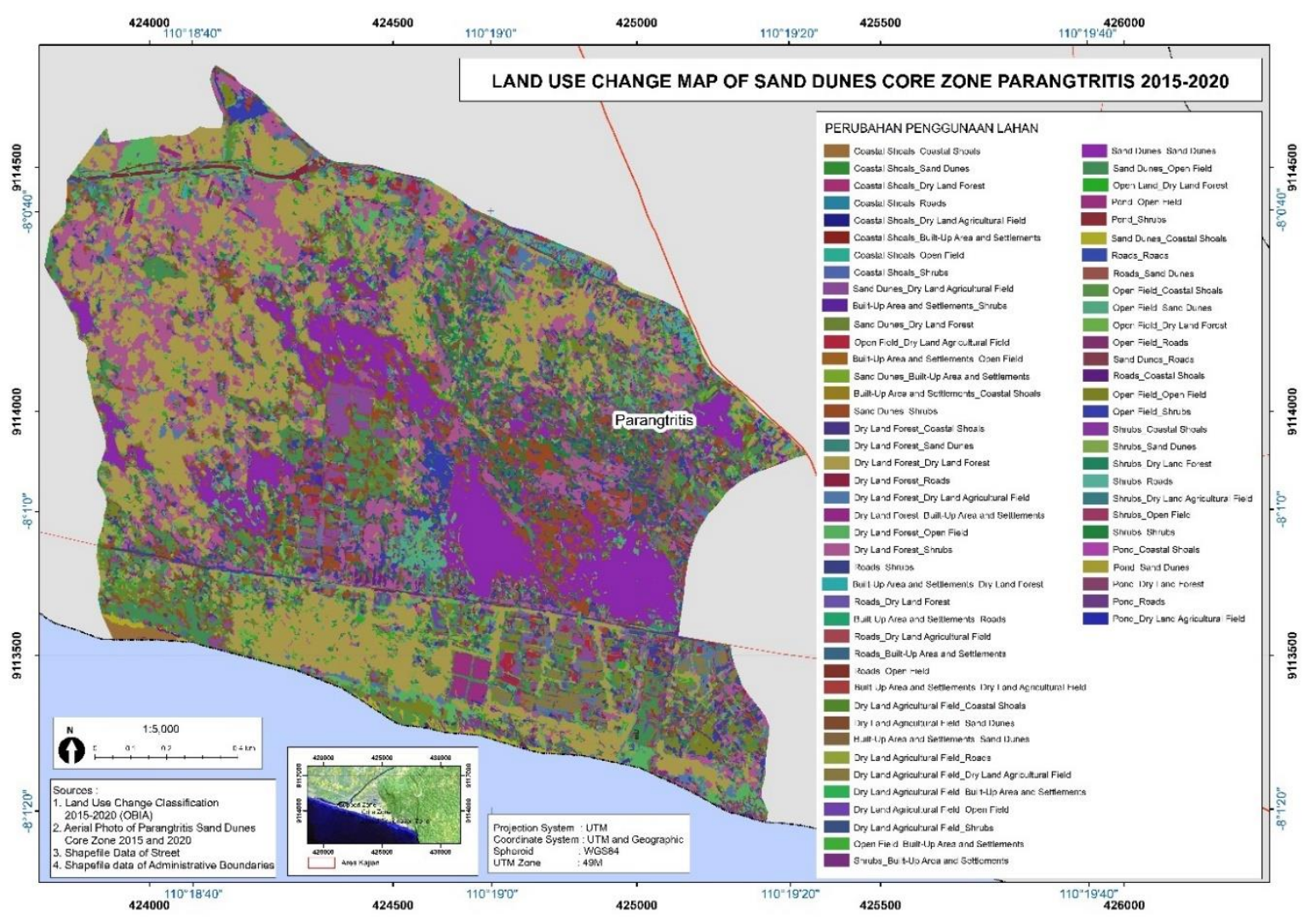

Figure 11. Land use change map for Parangtritis sand dune core zone

The map of land use change probably looks very complicated, but it illustrates that there are changes in every land use class (Figure 11). The highest change is the transition from dry land forests to shrubs.
This explains how the region has undergone a very dramatic rise in shrubs, where most of these changes affected by the dry land forest shift. As previously mentioned, sand dunes are experiencing very drastic changes into 
other land uses, such as shrubs and open field. Amongst the other sand dune changes, these two changes are the biggest changes. Some areas of the core zone that were very clear of shrubs in 2015 are now overgrown with shrubs.

In fact, the changes that are very noticeable are the fishponds. Fishponds are one of the coastal communities' key livelihoods, so it is not surprising that many fishponds are found in the Parangtritis coastal areas. The issue is where the fishponds built. There were multiple sites in the core zone of the sand dune used for building fishponds in 2015. By 2020, however, the fishponds are no longer exist and translocated out of the sand dune's core zone. Even so, the pond does not return instantly to a sand dune and is left to become open field instead.

Changes that occur, whether they are major or minor, will definitely have an effect on sand dune development. Currently, there are no formal regulations on sand dunes, but there is a study by Universitas Gadjah Mada and the Geospatial Information Agency (BIG), which mentions recommendations for land use that should be in Parangtritis sand dunes. Based on existing studies, changes in sand dunes have not actually met the recommendations. In the sand dune core zone, one of the recommendations is to clear all vegetation in dry land forest. Based on Figure 9, there has indeed been a decrease in dry land forest area, but this still does not meet the recommended recommendations. Then, there is a recommendation for built-up area translocation, which until now has not been completed. Nevertheless, the built-up area in the southern part of the sand dune has been moved outside the core zone. The ponds have been translocated outside the sand dune, but efforts still needed to restore it to sand dune. Furthermore, the next recommendation to clear all vegetation up to 50 meters before the southern passage has clearly not been implemented yet, considering that dry land forest has not been eliminated.

Finally, some recommendations for the use of the core zone are for religious and spiritual activities, and limited special interest tourism activities (hiking, sandboarding, ATV). It has been a long time since sand dunes have provided these functions, but there has been no further information about the limitation, so the conformity of these activities with the recommendation could not be explained.

\section{CONCLUSION}

Land use change mapping in the core zone of the sand dune using the OBIA method produced relatively accurate results, with overall accuracy $61.81 \%$ for 2015 and $68.95 \%$ for 2020 . There are changes in every land use class, where the most significant changes are changes in sand dunes, dry land forest, fishponds, built-up area, and shrubs.

\section{ACKNOWLEDGMENT}

The author would like to thank Parangtritis Geomaritime Science Park who has provided data for this research.

\section{REFERENCES}

Asma, N. (2018). Anaisa Perubahan Lahan Tambak Menggunakan Metode Maximum Likelihood (StudiKasus: Kota Banda Aceh). Universitas Syiah Kuala.

Budiyanto, G. (2011). Teknologi Konservasi Lanskap Gumuk Pasir Pantai Parangtritis Bantul DIY. Jurnal Lanskap Indonesia, 3(2).

Congalton, R., \& Green, K. (2008). Assessing the Accuracy of Remotely Sensed Data: Principles and Practices (Second Edi). CRC Press.

Hay, G. ., \& Castilla, G. (2006). Object-Based Image Analysis Strengths, Weakness, Opportunities And Threats (SWOT). The International Archives of the Photogrametry, Remote Sensing and Spatial Information Sciences.

Hendrastuti, B., Ibrahim, F., \& Wahyuningsih, D. S. (2018). Evaluasi Implementasi Kajian Restorasi Kawasan Kagungan Dalem Gumuk Pasir Parangtritis. Prosiding Seminar Nasional Geotik 2018, 205-213.

Laily, A. N., Sawiji, A., \& Junaidi, R. (2018). Kajian Dinamika Penggunaan Lahan 
Zona Inti Gumuk Pasir Tipe Barkhan Pasca Restorasi di Parangtritis, Bantul, Yogyakarta. Seminar Nasional Geomatika 2018

Setiani, A., Prasetyo, Y., \& Subiyanto, S. (2016). Optimalisasi Parameter Segmentasi Berbasis Algoritma Multiresolusi Untuk Identifikasi Kawasan Industri Antara Citra Satelit Landsat dan ALOS PALSAR. Jurnal Geodesi Undip, 5(4), 112-121.

Sihotang, W. M. (2014). Analisa Pengaruh Parameter Oseanografi Terhadap Sebaran Gumuk Pasir Di Parangtritis Tahun 2005-2009. Jurnal Oseanografi, 3(2), 246-256.

Simamora, F. B., Sasmito, B., \& Haniah. (2015). Kajian Metode Segmentasi Untuk Identifikasi Tutupan Lahan dan Luas Bidang Tanah Menggunakan Citra Pada Google Earth (Studi Kasus : Kecamatan Tembalang, Semarang). Jurnal Geodesi Undip, 4(4), 43-51.

Sirin, D. N. S., Salyasari, N. D., Maryanto, A., \& Widipaminto, A. (2015). Standarisasi
Prosedur Pengambilan Foto Udara dengan Pesawat LSA untuk Pengembangan Payload Inderaja. Seminar Nasional Penginderaan Jauh, 1-6. Subaryono, H., \& Kurniawan, E. (2008). Evaluasi Pembuatan Mosaik Foto Udara Format Kecil Tidak Terkontrol Menggunakan Perangkat Lunak Desain Grafis Komersial. Jurnal Media Teknik, 4, 261-268.

Syarif, A. M. (2017). Geospatial Object Based Image Analysis Foto Udara Format Kecil untuk Klasifikasi Penutup Lahan Skala Detil. Universitas Gadjah Mada.

Widayani, P. (2018). Aplikasi Object-Based Image Analysis untuk Identifikasi Awal Permukiman Menggunakan Citra Satelit WorldView-2. Majalah Geografi Indonesia, 162-169.

Yogyakarta Special Region Regulation Number 4 of 2015. (2015). Pelestarian Habitat Alami. Peraturan Daerah Nomor: 4 Tahun 2015. Gubernur Daerah Istimewa Yogyakarta. Yogyakarta. 